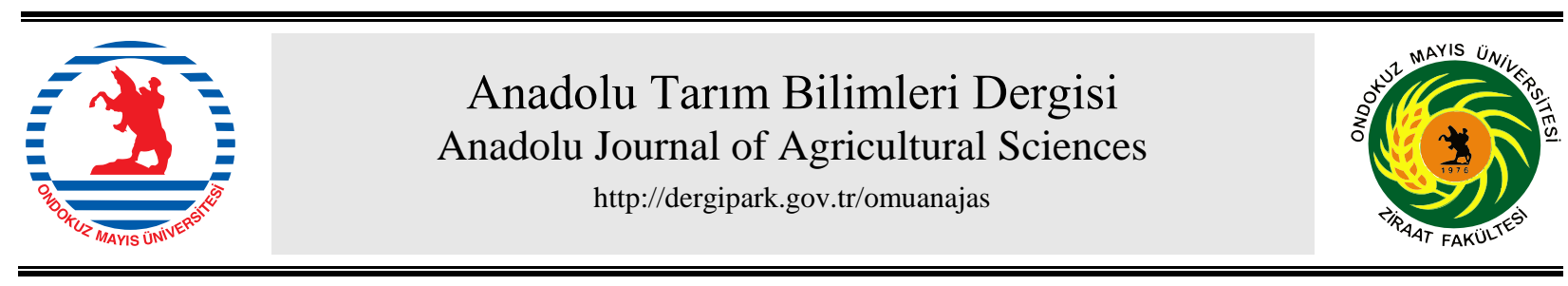

\section{Araştırma/Research}

Anadolu Tarım Bilim. Derg./Anadolu J Agr Sci, 34 (2019) ISSN: 1308-8750 (Print) 1308-8769 (Online) doi: $10.7161 /$ omuanajas.536346

\title{
Kurutma yöntemlerinin findığın fiziksel özellikleri üzerine etkisi
}

\author{
Ali Turan \\ Fındık Eksperlĭgi Programı, Teknik Bilimler Meslek Yüksek Okulu, Giresun Üniversitesi, 28100, Giresun, Türkiye \\ Sorumlu yazar/corresponding author: ali.turan@giresun.edu.tr; alituran61@gmail.com
}

Geliş/Received 06/03/2019 Kabul/Accepted 29/07/2019

\section{ÖZET}

$\mathrm{Bu}$ çalışma geleneksel (beton ve çimen harman; BH, ÇH, sırasıyla) ve suni kurutma (kurutma makinesi, KM) yöntemlerinin Tombul, Palaz ve Ordu Levant findıklarının fiziksel özellikleri üzerine etkisini belirlemek amacıyla 2015 yılında yürütülmüştür. $\mathrm{Bu}$ amaçla, çalışmada meyve uzunluğu, meyve genişliği, meyve kalınlığı, iç uzunluğu, iç genişliği, iç kalınlığı, meyve büyüklüğü, meyve şekil indeksi, kabuk kalınlığı, göbek boşluğu, buruşuk iç oranı, meyve ağırlığı, iç ağırlığı, iç oranı, sağlam iç oranı (SİO), kusurlu iç oranı (KİO) ve beyazlama oranı gibi fiziksel özellikler incelenmiştir. Çalışma sonucunda, KM metodunda SİO değeri $\mathrm{BH}$ ve ÇH metotlarına göre daha yüksek bulunmuştur. Ayrıca KİO değeri en düşük olarak yine $\mathrm{KM}$ metodunda tespit edilmiştir. $\mathrm{Bu}$ yüzden $\mathrm{KM}$ metodunun findık kurutma için uygun olduğu söylenebilir.

Effects of drying methods on physcal properties of hazelnut

\section{ABSTRACT}

This study was conducted in 2015 and aimed to determine the effects of hazelnut drying machine (DM) and traditional-drying (concrete and grass ground; CG and GG, respectively) methods on the physical properties of Tombul, Palaz, and Ordu Levant cultivars. For this purpose, namely nut lenght, nut width, nut depth, kernel lenght, kernel width, kernel depth, nut size, shape index, shell thickness, kernel cavity, shrivel kernel ratio, nut weight, kernel weight, kernel percentage, good kernel (GK), defect kernel (DK), and blanching ability were analyzed. At the end of the study, the GK value was found higher in DM method than on CG and GG methods. Therefore, DM is suitable method for hazelnut drying.

\section{Giriş}

Kurutma çok sayıda gıda ürününde yaygın kullanılan en eski muhafaza yöntemlerinden birisi olup (Karam ve ark., 2016) aynı zamanda eşzamanlı 1sı ve nem transferinin gerçekleştiği kompleks bir süreç olarak bilinir. Diğer yandan kurutma, su aktivitesi değerini azaltarak gidaların uzun süre kalite özelliklerini güvenli bir şekilde muhafaza etmesine imkan sağlamaktadır (Zhou ve ark., 2018).

Genel olarak kurutma suni ve geleneksel olmak üzere ikiye ayrılır (Maisnam ve ark., 2017) ve geleneksel kurutma güneş altında ve enerji tüketimi gerektirmediği için kullanımı en yaygın olanıdır. Suni kurutma yöntemleri ise enerji tüketimi ve maliyeti
Anahtar Sözcükler: Beyazlama oran1 Geleneksel kurutma Sağlam iç oranı Suni kurutma
Keywords:

Blanching ability

Traditional drying

Good kernel

Artificial drying

(C) OMU ANAJAS 2019 nedeniyle findık kurutmada ülkemizde yaygın değildir (Turan, 2017).

Kurutma yağ oranı yüksek findık gibi gıdalarda büyük önem taşımakta ve süreç uygun yürütülmezse yağ oksidasyonuna neden olmaktadır. Bu nedenle hasat sonrasında findığın meyve kalitesinin muhafazası için kurutma hayati önem taşımaktadır (Wang ve ark., 2018). Ülkemizde findık geleneksel olarak güneş altında beton ve çimen harmanda kurutulmaktadır (Turan, 2018; Turan ve İslam, 2018). Güneşte kurutma bir yandan çevre şartlarına bağlı olarak uzun zamanda gerçekleşerek yoğun işgücü kullanımına neden olurken (Yıldız, 2016) diğer yandan da meyve de kalite kaybına neden olarak raf ömrünü kısaltmaktadır (Turan, 2018). $\mathrm{Bu}$ nedenle findığın toplandıktan sonra zuruflarının 
ayrılması ve kısa sürede kurutulması büyük önem arz etmektedir. Çünkü geç kurutulan findıklarda, küf gelişimi ve zararlılar tarafindan hasar görme riski bulunmaktadır. Fındığın geleneksel yöntemlerle kurutulması (beton ve çimen harman) için yăğşsız ve güneşli günlere ihtiyaç duyulmaktadır (Turan ve İslam, 2018). Ancak, hasat sezonunda bölgenin ekolojisinden dolayı birbiri ardına devam eden güneşli günlere az rastlanmakta ve bu nedenle de bazı dönemlerde sürekli bir findık kurutma firsatı bulunamamaktadır (Keleş ve Sacilık, 2019).

Genel olarak güneşte kurutma yöntemlerinden beton harmanın, çimen harmandan findık kurutma için daha uygun olduğu kabul edilmekte, ancak bu konuda günümüze kadar detaylı çalışma bulunmamaktadır (Turan, 2018; Turan ve İslam, 2018). Hatta Türk findıklarında suni ve doğal kurutma yöntemlerinin meyve kalitesi üzerine etkileri konusunda kapsamlı bilgi bulunmamakla birlikte (Turan, 2017), findığın fiziksel özellikleri üzerine etkisi konusunda detaylı çalışma maalesef mevcut değildir (Turan ve İslam, 2018).

$\mathrm{Bu}$ çalışmanın amacı, güneşte kurutma ve suni kurutma yöntemlerinin Tombul, Palaz ve Ordu Levant findıklarının fiziksel özellikleri üzerine etkisini belirlemektedir. Çalışma sonucunda elde edilen veriler başta literatüre olmak üzere, findık ticareti ve sanayisine de önemli katkı sağlayacağı öngörülmektedir.

\section{Materyal ve Yöntem}

\subsection{Materyal}

Çalışma Tombul, Palaz ve Ordu levant findıklarında yürütülmüş ve örnekler Ordu ili Altınordu ilçesi Cumhuriyet mahallesinde tek bir bahçeden alınmıştır $\left(40^{\circ} 58^{\prime \prime} 21.72 \mathrm{~K}, 37^{\circ} 58^{\prime \prime} 48.14 \mathrm{D}\right.$, rakım $\left.43 \mathrm{~m}\right)$.

\subsection{Kurutma yöntemleri}

Hasat işlemi, 5-10 Ağustos 2015 tarihinde iç findığın nemi $\sim 28$ olduğunda yerden hasat şeklinde yapılmıştır. Nem değeri $103 \pm 2^{\circ} \mathrm{C}$ sıcaklıktaki firında ve atmosferik basınçta sabit kütleye ulaşıncaya kadar kurutularak belirlenmiştir (TS1632 EN ISO 665-2000; Refsan RK 55, Kütahya, Turkey; (TSE, 2001; Turan, 2017). Hasat edilen findıklar çimen harmana serilmiş ve çotanaklı halde $\sim 4$ gün soldurulmuştur (Tombul, Palaz ve Ordu Levant; \%22.00, 21.01 ve 19.00, sirasiyla; Çizelge

$1)$.

Çizelge 1. Fındığın soldurma öncesi ve sonrası nem değerleri ile kurutma süreleri

\begin{tabular}{|c|c|c|c|c|c|c|c|c|}
\hline \multirow{3}{*}{ Çeşit } & \multirow{3}{*}{ M } & \multicolumn{6}{|c|}{$\operatorname{Nem}(\%)$} & \multirow{3}{*}{$\begin{array}{c}\text { Kurutma süres } \\
\qquad(\mathrm{sa})\end{array}$} \\
\hline & & \multicolumn{2}{|c|}{ Başlangıç } & \multicolumn{2}{|c|}{ Soldurma sonras 1} & \multicolumn{2}{|c|}{ Kurutma sonras 1} & \\
\hline & & Kabuk & İç & Kabuk & İç & Kabuk & İç & \\
\hline \multirow{3}{*}{ Tombul } & $\mathrm{BH}$ & \multirow{3}{*}{28.02} & \multirow{3}{*}{26.13} & \multirow{3}{*}{25.33} & \multirow{3}{*}{22.00} & 7.50 & 5.45 & 85 \\
\hline & ÇH & & & & & 8.10 & 6.00 & 96 \\
\hline & KM & & & & & 8.00 & 6.02 & 25 \\
\hline \multirow{3}{*}{ Palaz } & $\mathrm{BH}$ & \multirow{3}{*}{27.96} & \multirow{3}{*}{25.00} & \multirow{3}{*}{24.96} & \multirow{3}{*}{21.01} & 7.75 & 6.24 & 76 \\
\hline & ÇH & & & & & 7.70 & 6.27 & 85 \\
\hline & KM & & & & & 7.69 & 6.32 & 26 \\
\hline \multirow{3}{*}{$\begin{array}{l}\text { Ordu } \\
\text { Levant }\end{array}$} & $\mathrm{BH}$ & \multirow{3}{*}{29.00} & \multirow{3}{*}{26.59} & \multirow{3}{*}{21.50} & \multirow{3}{*}{19.00} & 9.00 & 5.68 & 80 \\
\hline & $\mathrm{ÇH}$ & & & & & 9.23 & 6.75 & 88 \\
\hline & KM & & & & & 9.01 & 5.86 & 30 \\
\hline
\end{tabular}

Soldurulan findıklar (11-16 Ağustos 2015) daha sonra patoz yardımıyla (Dinçler Makine, FPHM 2500, Samsun, Turkey) çotanaklarından ayrılmış ve kurutma işlemi için üç gruba ayrılmıştır. Grup I; çotanaklarından ayrılmış findıklar otu motorla biçilmiş (Oleo-Mac 440 $\mathrm{T}$, Italy) çimen harmana (ÇH; $4 \times 3 \mathrm{~m}$ boyut, $30 \mathrm{~kg}$ findık her çeşit için) getirilmiş ve yere serilen branda üzerine (TS 4739, TS 1534-2; EN ISO 2286-2, Kale Tente, İstanbul, Turkey) $5 \mathrm{~cm}$ kalınlığında serilmiş ve güneş altında günde en az 3 defa (sabah, öğle ve akşam) karıştırılmıştır. Grup II; findıklar doğrudan beton harmana (BH; $5 \times 5 \mathrm{~m}$ boyut, $30 \mathrm{~kg}$ findık her çeşit için) serilmiş (TS EN 12390 Gümüşteş Çimento, Giresun, Türkiye) ve güneş altında iklime bağlı olarak günde en az 3 defa karıştırılmıştır. ÇH ve $\mathrm{BH}$ metotlarında örnekler ortam şartlarında kurutulmuştur (ortalama rüzgar hızı, ortam sıcaklığı ve nemi ve güneşlenme süresi; $1.2 \mathrm{sa} \mathrm{km}^{-1}, 25.7^{\circ} \mathrm{C}$ ve $5.45 \mathrm{sa}$, sirasılya; MGM, 2015). C H ve $\mathrm{BH}$ metotlarında kurutma işlemi her gün saat 08:00-20:00 arasında devam etmiş ve 20:00'dan sonra findıkların nem almaması için üzeri naylon örtü (Metroplast, İstanbul, Türkiye) ile örtülmüştür (Yaygın uygulama). Grup III; findıklar kurutma makinesi (KM) içerisine elevatör yardımıyla yerleştirilmiş (3000 kg her çeşit için) ve kurutma işlemi $45^{\circ} \mathrm{C}$ 'de (yaygın kullanım) (FACMA ES 3000, 2013; Turan, 2017) gerçekleştirilmiştir (her çeşit için tesadüfen $30 \mathrm{~kg}$ seçilmiştir). Sıcak hava ventilator $\left(1.5 \mathrm{~m} \mathrm{~s}^{-1}\right.$ hava hızı) yardımıyla kurutucuya iletilmiş ve kurutma süresince arşimet vidası sürekli karıştırma işlemine devam etmiştir. Kurutma süresince 3 sa sicak hava pompalanmış ve 1.5 sa durdurulmuştur. $\mathrm{Bu} 1.5 \mathrm{sa}$ süresince ve kurutma süresince saat 20:00-08:00 aras1 dahil arşimet vidası karıştırma işlemine devam etmiştir. 
Kurutma işlemi iç fındık nem değeri \%7'nin altına düşene kadar devam ettirilmiştir (TSE, 2001; Köksal, 2002; Turan, 2017). ÇH, BH ve KM metotlarında nem değişimleri ve kuruma süreleri ile ilgili detaylar Çizelge 1 'de verilmiştir. Kurutma işlemi 17-22 Ağustos 2015 tarihleri arasında Ordu ili, Altınordu ilçesi, Karapınar mahallesi $\left(40^{\circ} 58^{\prime \prime} 17.53 \mathrm{~K}, 37^{\circ} 56^{\prime \prime} 00.41 \mathrm{D}\right.$, rakım 43 $\mathrm{m}$ ), Organize Sanayi Bölgesinde (Ordu OSB, Gürsoy Tarımsal Ürünler Gıda Sanayi ve Ticaret A.Ş. Entegre Tesisi) yürütülmüştür. Her bir ortamdan tesadüfen $\sim 2.250$ g örnek (3x750g tek.) alınmış ve $\sim 20 \mathrm{~kg}$ findık kurutma işlemi sonrasında (Arda kalan diğer örnekler ise kimyasal analizlerde kullanılmıştır) Ordu Ziraat Fakültesinde analiz yapılana kadar oda şartlarında (20$25^{\circ} \mathrm{C}, \% 70-90$ Nispi nem) jüt çuvalda bekletilmiştir.

\subsection{Kabuk ve iç özellikleri}

Ortalama meyve ve iç boyutları belirlemek için her çeşitten 270 findık tesadüfen seçilmiş (tekerrürde 30 meyve) ve toplam 810 meyve kullanılmıştır. Hosseinpour ve ark. (2013) tarafindan kullanilan metoda benzer, $0.01 \mathrm{~mm}$ hassasiyette dijital kumpas (BMI 7702200, Germany) ile findıkların (kabuklu ve iç findıklar) uzunluk (MU), genişlik (MG) ve kalınlık (MK) boyutları ölçüldü (Şekil 1) ve 30 meyvenin aritmetik ortalaması alınarak hesaplandı. Meyve büyüklüğü (MB), her çeşitten tesadüfen alınan 270 meyvenin meyve uzunluğu, meyve genişliği ve meyve kalınlığının geometrik ortalaması alınarak hesaplanmıştır (Turan, 2017).

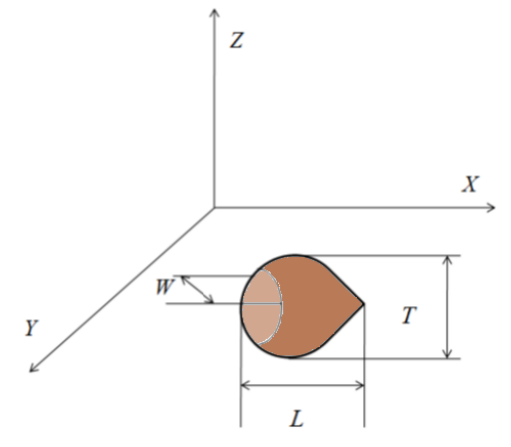

Şekil 1. Kabuklu ve iç findığın meyve boyutları (L: Meyve uzunluğu, T: Meyve kalınlığı, W: Meyve genişliği)

Meyve şekil indeksi (MŞí) aşağıdaki formül ile hesaplanmıştır (Turan ve Beyhan, 2009) (1).

$$
\mathrm{MSS \dot {I }}=\frac{\mathrm{MU}}{\mathrm{MG}}=\frac{\mathrm{MU}}{\frac{\mathrm{MG}+\mathrm{MK}}{2}}
$$

Kabuk kalınlığı (KK), findık tablasından yukarıya doğru orta veya ortaya yakın kısmından şişkin yerin en kalın yerinden $0.01 \mathrm{~mm}$ 'ye duyarlı kumpas kullanılarak tesadüfen seçilen toplam 30 meyve üzerinde yapılmıştır (İslam ve ark., 2005). Göbek boşluğu (GB), birleşen iki kotiledon arasında kalan boşluk göbek boşluğu olarak ifade edilmektedir. Göbek boşluğunun en geniş çapı $0.01 \mathrm{~mm}$ 'ye hassas kumpas ile ölçülmüş ve $\mathrm{mm}$ olarak ifade edilmiş ve ölçümler 30 meyvede yapılmıştır. Buruşuk iç oranı (BRŞ), genellikle ürünün bol olduğu yıllarda veya kuraklık ve beslenme yetersizliği gibi etkenler nedeniyle veya kalıtsal olarak meydana gelen ve bir meyvenin dış yüzeyinin yaklaşık \%50'sinden fazla bir kısmının buruşuk olması olarak tanımlanır. Çalışmada \%50 değerinin altında kalanlarda buruşuk iç olarak değerlendirilmiştir. Bu özellik buruşuk içlerin yüzdesi (\%) olarak belirlenmiş ve 50 meyve üzerinden yapılmıştır. Meyve ve iç ağırlığı tesadüfen seçilen 30 meyve 0.01 g'a duyarl terazide (Vibra, HJR-4200CE, Japan) tek tek tartılıp aritmetik ortalaması alınarak hesaplanmıştır (Turan, 2017) (2)

$$
\mathrm{MA}(\mathrm{g})=\Sigma \mathrm{Xi} / \mathrm{n}
$$

İç oranı (İO), toplam meyve ağırlığının toplam iç (dolgun ve kusurlu içler) ağırlığına oranlaması yoluyla yüzde (\%) olarak hesaplanmıştır. Tesadüfen alınan 50 meyve kullanılarak yapılmıştır (Turan, 2017) (3).

$$
\text { İç Oranı }(\%)=\frac{\text { İç Ağırlığı }}{\text { Meyve Ağırlığı }} \times 100
$$

Sağlam iç oranı (Sİ), sert kabuğu tamamen doldurmuş kusurlu olmayan içlerin toplam içe oranlanmasıyla bulunmuştur. Tesadüfen seçilen 50 meyve kullanılmış, yüzde (\%) olarak ifade edilmiştir (4).

$$
\text { SíO (\%) }=\frac{\text { Kusurlu olmayan iç (Adet) }}{\text { Toplam İ̧̧ (Adet) }} \times 100
$$

Kusurlu iç oranı (KİO), dolgun içli meyveler ile boş içli meyveler dışındaki meyvelerden elde edilen içlerin (abortif, buruşuk, küflü ve çürük) toplam meyve adedine oranlanmasıyla bulunmuştur. Ölçümlerde 50 meyve kullanılmış, yüzde (\%) olarak ifade edilmiştir (5).

$$
\text { KİO (\%) }=\frac{\text { Kusurlu iç (Adet) }}{\text { Toplam İç (Adet) }} \times 100
$$

Beyazlama oranı (BO), sağlam iç findıklar firında (Refsan RK 55, Kütahya, Turkey) $175^{\circ} \mathrm{C}^{\prime}$ de 15 dakika bekletilmiş, daha sonra el ile 15-20 saniye ovularak testa çıkarılmış ve aşağıdaki formülü ile hesaplanmıştır (Turan ve Beyhan, 2009) (6).

$$
\mathrm{BO}(\%)=\frac{\text { Beyazlamış iç }}{\text { Toplam iç }} \times 100
$$

\subsection{Istatistiksel analizler}

Demene tesadüf blokları deneme desenine göre 3 tekerrülü olarak yürütülmüştür. Tanımlayıcı istatistikler SAS-JAMP v. 10.0 (SAS Institute Inc., Cary, North Carolina) kullanılarak yapılmış̧ır. Çoklu karşılaştırmada en küçük anlamlı fark (LSD) yöntemi ve 
seviyeler arasındaki önemli farklılıkları değerlendirmede One-way ANOVA kullanılmıştır. Sonuçlar arasındaki farklılık $\mathrm{P}<0.05$ düzeyinde belirlenmiştir.

\section{Bulgular ve Tartışma}

\subsection{Kurutma yöntemlerinin kabuk ve iç meyve özellikleri üzerine etkisi}

Meyve boyutları üzerine çeşit, besleme, verim, ekoloji ve hasat zamanı gibi pek çok faktör etki etmektedir (Turan, 2017). Ayrica meyve uzunluğu (MU), meyve genişliği (MG) ve meyve kalınlığının (MK) kalıtım derecesinin yüksek olduğu $\left(h^{2}=0.68,0.78\right.$ ve 0.89 , sirasiyla) bilinmektedir (Yao ve Mehlenbacher, 2000). Çalışmada meyve ve iç boyutları üzerine kurutma yöntemlerinin etkisi önemsiz çıkmış ( $\mathrm{p}>0.05)$, MU 15.71-18.04 mm, MG 17.40-19.62 ve MK 15.79$17.22 \mathrm{~mm}$ arasında değişmiş, ancak çeşitler arasındaki farklılık istatistikî olarak önemli bulunmuştur $(\mathrm{p}<0.05$; Çizelge 2). En yüksek MU değerleri Tombul (17.53$18.04 \mathrm{~mm}$ ), MG ve MK değerleri Palaz (19.16-19.62 $\mathrm{mm}, 16.65-17.22 \mathrm{~mm}$, sırasıyla) çeşidinde kaydedilmiş ve en küçük değerler yine çeşitlere göre farklılık göstermiştir $(p<0.05)$. Benzer şekilde Özdemir ve
Akinci (2004) ve Ercişli ve ark. (2011) MU, MG ve MK değerlerinin Palaz, Tombul ve Çakıldak çeşitlerine göre farklılık göstediğini $(15.56 \mathrm{~mm}, 18.16 \mathrm{~mm}, 16.17 \mathrm{~mm}$; $16.22 \mathrm{~mm}, 16.66 \mathrm{~mm}, 15.79 \mathrm{~mm}$ ve $18.55 \mathrm{~mm}, 16.80$ mm, $15.67 \mathrm{~mm}$, sırasıyla) bildirmişlerdir. Ayrıca Aydın (2002) tarafindan yürütülen çalışmada, Tombul çeşidinin MU, MG ve MK (18.03, 18.97 ve 16.58, sırasıyla) değerlerinin çalışmamıza benzer boyutlarda olduğu görülmüsştür. Çalışmamızda ayrıca iç özellikleri de çeşitlere göre farklılık göstermiştir. Şöyle ki; en yüksek İG ve İK Ordu Levant (14.31-16.02 mm; 13.29$14.06 \mathrm{~mm}$, sirasıyla), en düşük ise Palaz (14.55-15.75 $\mathrm{mm} ; 12.80-13.97 \mathrm{~mm}$, sirasiyla) ve Tombul (12.64$13.69 \mathrm{~mm} ; 12.35-13.41 \mathrm{~mm}$, sirasıyla) çeşitlerinde belirlenmiştir. MU değeri ise en yüksek olarak Tombul (13.13-13.99 mm) çeşidinde kaydedilmiştir. Fındıklarda iç meyvenin fiziksel özelliklerinin çeşitlere göre farklılık gösterdiği pek çok çalışmada da görülmüştür (Ercişli ve ark., 2011; Turan, 2017; Turan ve İslam, 2018). Ayrıca iç meyve boyutlarının Xu ve Hanna (2010)'a göre yıldan yıla (2007: İU ve İG; 12.1, 12.3 mm, sırasiyla; 2008: IUU ve İG; 11.4, $10.7 \mathrm{~mm}$, sirasıyla) ve Pliestic ve ark. (2006)'na göre ise türlere göre (Corylus maxima cv. Istrian long; 20.20, $14.52 \mathrm{~mm}$, sırasıyla) değişkenlik gösterdiği bildirilmiştir.

Çizelge 2. Kurutma yöntemlerinin meyve uzunluğu, meyve genişliği, meyve kalınlığı, iç uzunluğu, iç genişliği ve iç kalınlı̆̆ özellikleri üzerine etkisi

\begin{tabular}{cccccccc}
\hline \multirow{2}{*}{$C ̧$} & M & MU $(\mathrm{mm})$ & MG $(\mathrm{mm})$ & MK $(\mathrm{mm})$ & İU $(\mathrm{mm})$ & IG $(\mathrm{mm})$ & İK $(\mathrm{mm})$ \\
\cline { 3 - 8 } Tombul & BH & $18.04 \pm 0.76$ & $17.40 \pm 0.33$ & $16.40 \pm 0.68$ & $13.99 \pm 0.45$ & $12.64 \pm 0.90$ & $13.41 \pm 1.12$ \\
& CH & $17.53 \pm 0.52$ & $18.26 \pm 0.40$ & $16.27 \pm 0.65$ & $13.18 \pm 0.43$ & $12.85 \pm 1.58$ & $12.35 \pm 0.40$ \\
& KM & $17.31 \pm 0.72$ & $18.05 \pm 1.13$ & $16.23 \pm 0.22$ & $13.13 \pm 0.77$ & $13.69 \pm 1.27$ & $12.86 \pm 0.27$ \\
\hline \multirow{3}{*}{ Palaz } & BH & $15.96 \pm 0.80$ & $19.06 \pm 0.24$ & $16.65 \pm 0.33$ & $12.33 \pm 0.75$ & $14.71 \pm 0.56$ & $13.39 \pm 0.15$ \\
& ÇH & $16.06 \pm 0.94$ & $19.62 \pm 0.72$ & $17.22 \pm 0.77$ & $12.04 \pm 0.67$ & $15.75 \pm 0.68$ & $13.97 \pm 0.56$ \\
& KM & $16.42 \pm 0.86$ & $18.57 \pm 0.78$ & $15.79 \pm 0.61$ & $12.45 \pm 0.50$ & $14.55 \pm 0.52$ & $12.80 \pm 0.50$ \\
\hline \multirow{2}{*}{ Ordu } & BH & $16.61 \pm 2.56$ & $18.50 \pm 0.64$ & $16.33 \pm 0.43$ & $12.92 \pm 2.19$ & $14.92 \pm 1.70$ & $13.33 \pm 0.53$ \\
Levant & ÇH & $15.71 \pm 1.54$ & $18.96 \pm 1.39$ & $16.46 \pm 0.87$ & $12.90 \pm 0.66$ & $14.31 \pm 1.00$ & $13.29 \pm 0.82$ \\
& KM & $15.97 \pm 0.07$ & $19.05 \pm 0.67$ & $16.59 \pm 0.61$ & $11.90 \pm 0.87$ & $16.02 \pm 0.41$ & $14.06 \pm 0.61$ \\
\hline \multirow{2}{*}{ Önem } & Ç & $*$ & $*$ & öd & $*$ & $* *$ & öd \\
& M & öd & öd & öd & öd & öd & öd \\
& ÇxM & öd & öd & odd & öd & öd & öd \\
\hline
\end{tabular}

Ç: Çeşit, M: Metot, BH: Beton harman, ÇH: Çimen harman, KM: Kurutma makinesi $\left(45^{\circ} \mathrm{C}\right)$. MU: Meyve uzunluğu, MG: Meyve genişliği, MK: Meyve kalınlığı, İU: İç uzunluğu, İG: İç genişliği, İK: İç kalınlığı. Değerler ortalama \pm standart sapma olarak ifade edilmiştir. Farklılıklar sütunlarda farklı harfle gösterilmiştir. Önem seviyesi; *, **, *** ve "öd"; $\mathrm{P}<0.05,0.01,0.001$ ve "önemli değil", sırasıyla

Ortalama meyve büyüklüğü (MB), meyve şekil indeksi (MŞİ), kabuk kalınlığı (KK), göbek boşluğu (GB) ve buruşuk iç oranı (BRŞ) değerleri Çizelge 3'de verilmiştir. Kurutma yöntemlerinin $\mathrm{MB}$ ve MŞİ değerleri üzerine etkisi olmazken, KK, GB ve BRŞ özellikleri çeşitlere göre farklılık göstermiştir $(\mathrm{p}<0.001)$. Tombul çeşidinde Palaz ve Ordu Levant findıklarına göre daha yüksek MB değeri tespit edilmiştir (Çizelge 3). Ortalama MB 17.17-17.33 mm, MŞI 1.01-1.07, KK 1.05-1.17 mm, GB 2.44-3.22 mm ve BRŞ değeri \%2.19-2.47 arasında değiştiği görülmüştür. Elde edilen bu değerler Delprete ve Sesana (2004), Turan ve Beyhan (2009), Ercişli ve ark. (2011), Turan (2017) ve Karaosmanoğlu ve Üstün (2017) ile benzerlik göstermiştir.

Ayrıca çalışmada kurutma yöntemlerinin özellikler üzerine etkisi çeşitlere göre de farklılık göstermiştir. Örneğin, en düşük BRŞ oranı Palaz ve Ordu Levant findıklarında $\mathrm{KM}$ ortamında $(\% 1.01$ ve $\% 4.17$, sırasıyla), Tombul çeşidinde en düşük değer ise $\mathrm{BH}$ 
(\%8.28) metodunda kaydedilmiştir. Tespit edilen bu farklılıklar kurutma yöntemi ve çeşit gibi özelliklere ilaveten klonal farklılıktan da kaynaklanmış olabilir. Çünkü Türk findık çeşitlerinde genel olarak büyük bir klonal varyasyon olduğu bilinmektedir (Turan ve Beyhan, 2009). Ayrıca Kalkışım ve ark. (2016) yükseklik ve hasat zamanına göre findıklarda meyve ve iç özelliklerinin değişebileceğini bildirmiştir.
Meyve ağırlığı (NW), iç ağırlığı (KW), iç oranı (IOO), sağlam iç oranı (SİO), kusurlu iç oranı (KİO) ve beyazlama oranı (BO) değerlerinin kurutma yöntemlerine göre değişimi Çizelge 4'de verilmiştir. Kurutma yöntemlerinin etkisi İA ve İO haricinde istatistiksel olarak önemli bulunmuştur $(\mathrm{p}<0.001$; Çizelge 4). Ayrıca İO haricinde tüm morfolojik özellikler çeşitlere göre farklılık göstermiştir $(\mathrm{p}<0.001)$.

Çizelge 3. Kurutma yöntemlerinin meyve büyüklüğü, meyve şekil indeksi, kabuk kalınlığı, göbek boşluğu ve buruşuk iç oranı özellikleri üzerine etkisi

\begin{tabular}{ccccccc}
\hline & & \multicolumn{5}{c}{ Özellik } \\
\cline { 3 - 7 } Çeşit & M & MB & MŞİ & KK (mm) & GB (mm) & BRŞ (\%) \\
\hline \multirow{3}{*}{ Tombul } & BH & $17.27 \pm 0.47$ & $1.07 \pm 0.02$ & $0.96 \pm 0.02$ & $1.27 \pm 0.01 \mathrm{f}$ & $8.28 \pm 0.53 \mathrm{~b}$ \\
& CH & $17.33 \pm 0.47$ & $1.02 \pm 0.02$ & $0.96 \pm 0.04$ & $1.16 \pm 0.01 \mathrm{f}$ & $10.33 \pm 0.43 \mathrm{a}$ \\
& KM & $17.17 \pm 0.18$ & $1.01 \pm 0.07$ & $0.91 \pm 0.01$ & $1.88 \pm 0.19 \mathrm{e}$ & $10.04 \pm 0.07 \mathrm{a}$ \\
\hline \multirow{3}{*}{ Palaz } & BH & $17.17 \pm 0.30$ & $0.89 \pm 0.05$ & $1.05 \pm 0.04$ & $2.25 \pm 0.03 \mathrm{cde}$ & $2.32 \pm 0.28 \mathrm{e}$ \\
& ÇH & $17.57 \pm 0.81$ & $0.87 \pm 0.02$ & $1.08 \pm 0.03$ & $2.19 \pm 0.08 \mathrm{cde}$ & $2.02 \pm 0.02 \mathrm{e}$ \\
& KM & $16.88 \pm 0.01$ & $0.96 \pm 0.08$ & $1.08 \pm 0.04$ & $2.47 \pm 0.01 \mathrm{bcd}$ & $1.01 \pm 0.01 \mathrm{e}$ \\
\hline \multirow{2}{*}{ Ordu } & BH & $17.08 \pm 0.65$ & $0.96 \pm 0.17$ & $1.17 \pm 0.02$ & $2.54 \pm 0.53 \mathrm{bc}$ & $6.88 \pm 1.61 \mathrm{bc}$ \\
Levant & ÇH & $16.99 \pm 1.22$ & $0.89 \pm 0.04$ & $1.18 \pm 0.12$ & $3.22 \pm 0.33 \mathrm{a}$ & $6.37 \pm 0.73 \mathrm{c}$ \\
& KM & $17.15 \pm 0.42$ & $0.90 \pm 0.03$ & $1.05 \pm 0.02$ & $2.88 \pm 0.42 \mathrm{ab}$ & $4.17 \pm 1.71 \mathrm{~d}$ \\
\hline \multirow{2}{*}{ Önem } & Ç & öd & öd & $* * *$ & $* * *$ & $* * *$ \\
& M & öd & öd & $*$ & öd & $*$ \\
& CxM & öd & öd & öd & $* *$ & $* *$ \\
\hline
\end{tabular}

Ç: Çeşit, M: Metot, BH: Beton harman, ÇH: Çimen harman, KM: Kurutma makinesi $\left(45^{\circ} \mathrm{C}\right) . \mathrm{MB}$ : Meyve büyüklüğü, MŞi: Meyve şekil indeksi, KK: Kabuk kalınlığı, GB: Göbek boşluğu, BRŞ: Buruşuk iç oranı. Değerler ortalama \pm standart sapma olarak ifade edilmiştir. Farkl1lıklar sütunlarda farklı harfle gösterilmiştir. Önem seviyesi; *, **, *** ve "öd"; $\mathrm{P}<0.05,0.01,0.001$ ve "önemli değil”, sirasiyla

Çizelge 4. Kurutma yöntemlerinin meyve ağırlığı, iç ağırlığı, iç oranı, sağlam iç oranı, kusurlu iç oranı ve beyazlama oranı özellikleri üzerine etkisi

\begin{tabular}{|c|c|c|c|c|c|c|c|}
\hline \multirow[b]{2}{*}{ Çeşit } & \multirow[b]{2}{*}{ M } & \multicolumn{6}{|c|}{ Özellik } \\
\hline & & MA (g) & İA $(\mathrm{g})$ & İO (\%) & SİO (\%) & KİO (\%) & $\mathrm{BO}(\%)$ \\
\hline \multirow{3}{*}{ Tombul } & $\mathrm{BH}$ & $1.68 \pm 0.01 \mathrm{de}$ & $0.86 \pm 0.01 \mathrm{dd}$ & $52.21 \pm 0.28 \mathrm{ab}$ & $88.19 \pm 0.61 \mathrm{c}$ & $11.81 \pm 0.61 \mathrm{~b}$ & $97.33 \pm 0.58 \mathrm{a}$ \\
\hline & ÇH & $1.67 \pm 0.01 \mathrm{de}$ & $0.85 \pm 0.00 \mathrm{~cd}$ & $50.42 \pm 0.61 \mathrm{c}$ & $82.03 \pm 1.89 \mathrm{~d}$ & $17.97 \pm 1.89 \mathrm{a}$ & $97.02 \pm 0.09 \mathrm{a}$ \\
\hline & KM & $1.69 \pm 0.01 \mathrm{~cd}$ & $0.86 \pm 0.00 \mathrm{~cd}$ & $50.38 \pm 0.55 \mathrm{c}$ & $88.67 \pm 0.21 \mathrm{c}$ & $11.33 \pm 0.21 \mathrm{~b}$ & $97.32 \pm 0.84 \mathrm{a}$ \\
\hline \multirow{3}{*}{ Palaz } & $\mathrm{BH}$ & $1.68 \pm 0.01 \mathrm{de}$ & $0.88 \pm 0.01 b c$ & $52.09 \pm 0.17 \mathrm{ab}$ & $92.87 \pm 0.44 b$ & $7.13 \pm 0.44 c$ & $95.16 \pm 1.38 \mathrm{ab}$ \\
\hline & ÇH & $1.66 \pm 0.01 \mathrm{e}$ & $0.85 \pm 0.01 \mathrm{~cd}$ & $52.13 \pm 0.93 \mathrm{ab}$ & $92.65 \pm 0.56 b$ & $7.35 \pm 0.56 \mathrm{c}$ & $95.99 \pm 0.12 \mathrm{ab}$ \\
\hline & KM & $1.66 \pm 0.01 \mathrm{e}$ & $0.84 \pm 0.01 \mathrm{~d}$ & $51.81 \pm 0.34 a b c$ & $95.33 \pm 1.16 \mathrm{a}$ & $4.67 \pm 1.16 \mathrm{~d}$ & $94.36 \pm 1.50 \mathrm{~b}$ \\
\hline \multirow{3}{*}{$\begin{array}{c}\text { Ordu } \\
\text { Levant }\end{array}$} & $\mathrm{BH}$ & $1.71 \pm 0.11 \mathrm{c}$ & $0.97 \pm 0.02 \mathrm{a}$ & $51.38 \pm 1.53 \mathrm{abc}$ & $88.19 \pm 0.40 \mathrm{c}$ & $11.81 \pm 0.40 \mathrm{~b}$ & $95.35 \pm 0.31 \mathrm{ab}$ \\
\hline & ÇH & $1.76 \pm 0.03 b$ & $0.94 \pm 0.05 \mathrm{a}$ & $51.64 \pm 1.71 \mathrm{abc}$ & $82.57 \pm 2.42 \mathrm{c}$ & $17.43 \pm 2.42 \mathrm{a}$ & $89.29 \pm 1.00 \mathrm{c}$ \\
\hline & KM & $1.89 \pm 0.04 \mathrm{a}$ & $0.96 \pm 0.04 \mathrm{a}$ & $52.54 \pm 0.41 \mathrm{ab}$ & $90.93 \pm 1.74 b$ & $9.07 \pm 1.74 \mathrm{c}$ & $89.18 \pm 0.74 \mathrm{c}$ \\
\hline \multirow{3}{*}{ Önem } & Ç & $* * *$ & $* * *$ & öd & $* * *$ & $* * *$ & $* * *$ \\
\hline & M & $* * *$ & öd & öd & $* * *$ & $* * *$ & $* *$ \\
\hline & ÇxM & $* * *$ & $*$ & $*$ & $* *$ & $* *$ & ** \\
\hline
\end{tabular}

Ç: Çeşit, M: Metot, BH: Beton harman, ÇH: Çimen harman, KM: Kurutma makinesi $\left(45^{\circ} \mathrm{C}\right)$. MA: Meyve ağırlı̆̆ı, İA: İç ağırlığı, İO: İç oranı, SİO: Sağlam iç oranı, KİO: Kusurlu iç oranı ve BO: Beyazlama oranı. Değerler ortalama \pm standart sapma olarak ifade edilmiştir. Farkll1ıklar sütunlarda farklı harfle gösterilmiştir. Önem seviyesi; *, **, *** ve "öd"; P<0.05, 0.01, 0.001 ve “önemli değil”, sırasıyla

MA değeri üzerine kurutma yöntemlerinin etkisi ise çeşitlere göre farklılık göstermiştir. Örneğin, Tombul ve Palaz çeşitlerinde kurutma yöntemlerinin etkisi önemsiz bulunurken, Ordu Levant findıklarında KM $(1.89 \mathrm{~g})$ ortamında $\mathrm{BH}$ ve ÇH (1.71 g ve $1.76 \mathrm{~g}$, sirasıly) ortamlarına göre daha yüksek değerler elde edilmiş ve 300 aradaki farklılık önemli bulunmuştur $(\mathrm{p}<0.001)$. Ancak Turan (2017) kurutma yöntemlerinin MA değerini etkilemediğini bildirmiştir. Ayrıca Yao ve Mehlenbacher (2000) MA değerinin kalıtım değerinin $\left(h^{2}=0.63\right)$ yüksek olduğunu, İA değerinin ise kalıtım derecesinin $h^{2}=0.67$ olduğu bildirmiş, çalışmamızda ise 
kurutma yöntemlerinin bu özelliği etkilemediği görülmüştür. Ancak çeşitler arasındaki farklılık önemli bulunmuş $(\mathrm{p}<0.001)$ ve Ordu Levant findıklarında (0.94-0.97 g), Tombul $(0.85-0.86 \mathrm{~g})$ ve Palaz $(0.84$ $0.88 \mathrm{~g}$ ) çeşitlerine göre daha yüksek İA değeri tespit edilmiştir. Tespit edilen bu farklılıklarda çeşitlerin uzak akraba olmalarının (Kafkas ve ark., 2009) da etkili olduğu söylenebilir.

Randıman (iç oranı; İO) fındığın en önemli özelliklerinden birisidir ve findık fiyatı $\% 50$ randımana göre belirlenmektedir (Turan, 2017). Çalışmamızda kurutma yöntemlerinin İO üzerine etkisi önemsiz bulunmuştur ( $p>0.05$; Çizelge 4$)$ ve İO değeri \%52.3252.70 aralığında değişmiştir. Benzer șekilde Bostan (1999) ve Turan (2017) kurutma yöntemlerinin İO üzerine etkili olmadığını ve tespit edilen farklılıkların çeşitlerden kaynaklandığını bildirmişlerdir. İO özelliğinin çeşitlere göre farklılık gösterdiği bilinmekte birlikte (Turan, 2017), verim, ekoloji ve bakım şartlarından aşırı derecede etkilenmediği, bunun nedeninin ise kalıtım derecesinin yüksek $\left(h^{2}=0.87\right.$; [Yao ve Mehlenbacher, 2000]) olmasından kaynaklandığı bildirilmiştir. Ayrıca İO aynı çeşit içerisinde yıl ve lokasyon farkına göre de çok az düzeyde varyasyon göstermektedir (Hosseinpour ve ark., 2013)

Fındıkta yapılan kültürel uygulamaların verimi arttırmanın yanında sağlam iç oranını (SİO) yükseltmeye yönelik de olduğu bilinmektedir. Çünkü SİO değerinin yüksek olması findığın pazar değerini arttırmaktadır. Kurutma yöntemlerinin SİO üzerine etkisi önemli bulunmuş $(\mathrm{p}<0.001)$, çeşitlere göre farklılık göstermiş ve detaylı olarak Çizelge 4'de verilmiştir. SíO değerleri Palaz çeşidinde (\%92.6595.33), Ordu Levant (\%82.57-90.93) ve Tombul (\%82.03-88.67) çeşitlerine göre daha yüksek bulunmuştur. Bu özelliği İslam (2000), Tombul \%94.33, Palaz \%90.75 ve Çakıldak çeşidinde \%80.75; Turan ve ark. (2010) ise y1ldan yıla değişmekle birlikte \%81.5892.56 arasında değiştiğini bildirmiştir. Çalışmalarda tespit edilen bu farklılıklar çeşit, budama, beslenme, ekoloji ve/veya klonal farklılıktan kaynaklanmış olabilir.

Kurutma yöntemlerinin SİO üzerine etkisi önemli bulunmuş ve detaylar Çizelge 4'de verilmiştir. Çalışmada Tombul, Palaz ve Ordu Levant findıklarında KM (\%95.33, 90.93, 88.67, sirasiyla) metodunda BH ve ÇH metotlarına göre daha yüksek SíO tespit edilmiştir. Benzer şekilde Turan ve İslam (2018) kurutma yöntemlerinin SİO üzerine etkili olduğunu ve ayrıca çeşitlere göre de farklılık gösterdiğini bildirmiştir. Kusurlu iç oranı (KIO) Palaz çeşidinde (\%4.67-7.35), Ordu Levant (\%9.07-17.43) ve Tombul (\%11.3317.97) çeşitlerine göre daha düşük gerçekleşmiştir. Benzer sonuçlar Turan (2017) tarafından tespit edilmiş ve KİO değerinin çeşitlere göre farklılık gösterdiği bildirilmiş̧ir. Kurutma yöntemleri arasında ise BH ve ÇH metotlarına göre KM metodunda daha düşük değerler (Tombul, Palaz ve Ordu Levant; \%11.33, 4.67, 9.07, sırasıyla) tespit edilmiştir. Tespit edilen bu farklı1ıklar, güneşte kurutmanın daha uzun sürede gerçekleşmesi ve örneklerin iklimsel faktörlerin etkisinde kalmasından kaynaklanmaktadır. Çünkü kurutma aşaması uzayan ve nem alan findıklarda içte çürüme meydana gelmektedir (Turan, 2017).

Beyazlama oranı (BO), ihraç edilecek ürünlerde aranan başlıca özelliklerden biridir ve yüksek olması arzu edilir (Turan, 2017). Toprak yapısı, ekoloji ve çeşit gibi pek çok özellik tarafından etkilenen BO'nın kalıtım derecesinin $h^{2}=0.64$ olduğu bilinmektedir (Yao ve Mehlenbacher, 2000). Çalışmamızda kurutma ortamların ve çeşidin BO üzerine etkisi önemli bulunmuş $\quad(p<0.001$; Çizelge 4) ve \%89-97.33 aralığında değişmiştir. Kurutma yöntemlerinin BO üzerine etkisi çeşitlere göre farklılık göstermiştir. Örneğin, Tombul çeşidinde kurutma ortamlarının etkileri arasında farklılık görünmezken Palaz ve Ordu Levant findıklarda farklı bulunmuştur. Genel olarak en yüksek değerler Tombul, Palaz ve Ordu Levant findiklarinda $\mathrm{BH}$ metodunda $(\% 0.97,0.95$ ve 0.95 , sırasıyla) kaydedilmiştir. Çalışmamızın aksine Bostan (1999) ise geleneksel kurutma yöntemlerinin BO üzerine etkili olmadığını, ancak tespit edilen farklılıkların çeşitlerden kaynaklandığını bildirmiştir.

Findıkta verim, meyve büyüklüğünü değiştiren en önemli etmenlerden birisi olarak bilinmektedir. Ayrıca tek bir çotanak içindeki meyveler arasında bile fiziksel farkl11ık görülmektedir (Turan, 2017). Çünkü verimin yüksek olduğu sezonlarda çotanaktaki meyve sayısı ve randıman artış gösterirken meyve büyüklüğü ve kabuk kalınlığı azalış göstermektedir. Hatta çotanaktaki meyve sayısının artışı meyvenin şekil değerinin değişmesine de neden olmaktadır. Bu nedenle de bir çeşit içinde bile meyvenin fiziksel özelliklerinde yıldan yıla değişkenlik gösteren farklılıklar gözlenmektedir.

\section{Sonuç}

$\mathrm{Bu}$ çalışma, geleneksel kurutma ve suni kurutma yöntemlerinin Tombul, Palaz ve Ordu Levant findıklarının fiziksel özellikleri üzerine etkisi konusunda yürütülen ilk çalışmadır. Kurutma yöntemlerinin findığın fiziksel özellikleri üzerine etkisi genellikle önemsiz çıkmış, ancak çeşitler arasındaki farklılık ise istatistiksel olarak önemli bulunmuştur. Çeşitlerin tamamında SİO değeri KM ortamında, BH ve ÇH ortamlarına göre daha yüksek bulunmuştur. Ayrıca KİO değeri $\mathrm{KM}$ ortamında diğer kurutma ortamlarına göre daha düşük kaydedilmiştir. Çalışma sonucunda elde edilen verilere dayanarak KM metodunun findık kurutma için gelecek vaat ettiği söylenebilir.

\section{Teşekkür}

Bu çalışma Gürsoy Tarımsal Ürünler Gıda Sanayi A.Ş (Ordu, Türkiye) desteklenmiştir. İstatistiksel analizler için Dr.Öğr.Üyesi Fatih ÖNER'e teşekkür ederim. 


\section{Kaynaklar}

Aydin, C., 2002. Physical properties of hazel nuts. Biosystems Engineering, 82 (3): 297-303. doi:10.1006/bioe.2002.0065.

Bostan, S.Z., 1999. Farklı ortamlarda kurutulan fındıklarda bazı önemli kalite özellikleri üzerine bir araştırma. Bahçe, 28: 73-78.

Delprete, C., Sesana R., 2004. Mechanical characterization of kernel and shell of hazelnuts: Proposal of an experimental procedure. Journal of Food Engineering, 124: 28-34. doi: 10.1016/j.jfoodeng.2013.09.027.

Ercisli, S., Öztürk, I., Kara, M., Kalkan, F., Seker, H., Duyar, O., Ertürk, Y., 2011. Physical properties of hazelnuts. International Agrophysics, 25: 115-121.

Hosseinpour, A., Seifi, E., Javadi, D., Ramezanpour, S.S., Molnar T.J., 2013. Nut and kernel characteristics of twelve hazelnut cultivars grown in İran. Scientia Horticulturea, 150: 410-413. doi: 10.1016/j.scienta.2012.11.028.

İslam, A. 2000. Ordu ilinde yetişen Türk findık çeşitlerinde klon seleksiyonu. Doktora Tezi. Çukurova Üniversitesi, Fen Bilimleri Enstitüsü, 192s, Adana.

İslam, A., Turan A., Kurt, H., 2005. Effect of ocak and single trunk training systems on yield and nut quality. Sixth International Congress on Hazelnut, Book of Proceeding, 259-262, 14-18 June, Tarragona-Reus, Spain. doi: 10.17660/ActaHortic.2005.686.35.

Kafkas, S., Doğan, Y., Sabır, A., Turan, A., Seker, H., 2009. Genetic characterization of hazelnut (Corylus avellana L.) cultivars from Turkey using molecular markers. Hort Science, 44(6): 1557-1561.

Kalkişim, O., Turan A., Okcu, Z., Özdeş, D., 2016. Evaluation of the effect of different harvest time on the fruit quality of foşa nut. Erwerbs-Obstbau, 58: 89-92. doi:10.1007/s10341-015-0259-1.

Karam, M.C., Petit J, Zimmer, D., Djantou E.B., 2016. Effect of drying grinding in production of fruit and vegetable powders: A review. Journal of Food Engineering, 188: 32-49. doi:10.1016/j.jfoodeng.2016.05.001.

Karaosmanoğlu, H., Üstün N.Ş., 2017. Organik ve konvansiyonel findikların (Corylus avellana L.) bazı fiziksel özellikleri. Akademik Gıda 15(4): 377-385. doi:10.24323/akademik-gida.370107

Köksal, A.İ., 2002. Türk Fındık Çeşitleri. Fındık Tanitım Grubu, 136s, Ankara.

Keleş, C.Ö., Sacılık, K., 2019. Basınçlı hava kullanılan infrared isiticili kurutucuda kabuklu findik kurutulması. Anadolu tarım Bilimleri Dergisi, 34: 65-72. doi:10.7161/omuanajas.434531.

Maisnam, D., Rasane, P., Dey, A., Kaur, S., Sarma, C., 2017. Recent advances in conventional drying of foods. J Food Technol Pres, 1: 25-34. MGM, 2015. Meteoroloji Genel Müdürlüğü.
https://mgm.gov.tr/?il=Ordu (Erişim tarihi: 22 Ağustos 2015).

Özdemir, F., Akinci, I., 2004. Physical and nutritional properties of four major commercial Turkish hazelnut varieties. Journal of Food Engineering, 63: 341-347. doi:10.1016/j.jfoodeng.2003.08.006.

Pliestic, S., Dobricevic, N., Filipoviç, D., GospodaricZ., 2006. Physical Properties of Filbert Nut andKernel. Biosystems Engineering 93(2): 173-178. doi:10.1016/j.biosystemseng.2005.11.008

TSE, 2001. İç Fındık Standardı. Türk Standartları Enstitüsü, TS 2075.

Turan, A., Beyhan, N., 2009. Investigation of the pomological characteristics of selected Tombul hazelnut clones in the Bulancak area of Giresun province. Seventh International Congress on Hazelnut, Book of Proceeding, 61-66, 23-27 June, Viterbo, Italy. doi:10.17660/ActaHortic.2009.845.4.

Turan, A., Ruşen, M., İslam, A., Kurt, H., Ak, K.Sezer, A., Sarıoğlu, M., Kalyoncu, İ.H., Kalkışım, Ö., 2010. Giresun koşullarında organik findık üretim imkanlarının araştırılması. Türkiye 4. Organik Tarım Sempozyumu, Bildiriler Kitabı, 123-129, 28 Haziran-1 Temmuz, Erzurum.

Turan, A., 2017. Findıkta Kurutma Yöntemlerini Meyve Kalitesi ve Muhafazası Üzerine Etkileri. Doktora Tezi. Ordu Üniveristesi, Fen Bilimleri Enstitüsü, 231s, Ordu.

Turan, A., İslam, A., 2018. Postharvest differences between 'Tombul' and 'Palaz'. IX International Congress on Hazelnut, pp: 351-358, 15-18 August, Samsun. doi:10.17660/ActaHortic.2018.1226.53.

Turan, A., 2018. Effect of Drying Methods on Fatty Acid Profile and Oil Oxidation of Hazelnut Oil During Storage. European Food Research and Technology, 12: 2181-2190. doi:10.1007/s00217018-3128-y.

Wang, W., Jung, J., McGorrin, R.J., Traber, M.G., Leonard, G.C., Zhao, Y., 2018. Investigation of drying conditions on bioactive compounds, lipid oxidation, and enzyme activity of Oregon hazelnuts (Corylus avellana L.). LWT-Food Science and Technology, 90: 526-534. doi:10.1016/j.lwt.2018.01.002.

Yao, Q., Mehlenbacher, S.A., 2000. Heritability, variance components and correlation of morphological and phenological traits in hazelnut. Plant Breeding, 119: 369-381. doi:10.1046/j.14390523.2000.00524.x.

Y1ld1z, T., 2016. Labor requirements and work efficiencies of hazelnut harvesting using traditional and mechanical pick-up methods. Turkish Journal of Agriculture and Forestry, 40:301-310. doi:10.3906/tar-1508-114.

Zhou, X., Wang, S., 2018. Recent developments in radio frequency drying of food and agricultural products: A review. Drying Technology, doi:10.1080/07373937.2018. 1452255. 
Xu, Y. X., Hanna, M.A., 2010. Evaluation of Nebraska hybrid hazelnuts: Nut/kernel characteristics, kernel proximate composition, and oil and protein properties. Industrial Crops and Products, 31: 84-91. doi:10.1016/j.indcrop.2009.09.005. 